\title{
Involvement of mitochondrial dysfunction in nefazodone-induced hepatotoxicity
}

\author{
Ana Marta Silva ${ }^{\mathrm{a}, \mathrm{b}}$, Inês A. Barbosa ${ }^{\mathrm{b}}$, Cátia Seabra ${ }^{\mathrm{b}}$, Nuno Beltrão ${ }^{\mathrm{b}}$, Raquel Santos ${ }^{\mathrm{b}}$, \\ Ignacio Vega-Naredo ${ }^{\mathrm{b}}$, Paulo J. Oliveira ${ }^{\mathrm{b}}$, Teresa Cunha-Oliveira ${ }^{\mathrm{b}, *}$ \\ ${ }^{a}$ University of Trás-os-Montes and Alto Douro (UTAD), Vila Real, Portugal \\ ${ }^{\mathrm{b}}$ Center for Neuroscience and Cell Biology, UC-Biotech Building, Biocant Park, University of Coimbra, Cantanhede, Portugal
}

\section{A R T I C L E I N F O}

\section{Article history:}

Received 21 March 2016

Received in revised form

10 May 2016

Accepted 3 June 2016

Available online 8 June 2016

\section{Keywords:}

Nefazodone

Mitochondria

Hepatotoxicity

Genotoxicity

Apoptosis

\begin{abstract}
A B S T R A C T
Nefazodone (NEF) is an antidepressive agent that was widely used in the treatment of depression until its withdrawal from the market, due to reports of liver injury and failure. NEF hepatotoxicity has been associated with mitochondrial impairment due to interference with the OXPHOS enzymatic activities, increased ROS generation and decreased antioxidant defenses. However, the mechanisms by which NEF induces mitochondrial dysfunction in hepatocytes are not completely understood. Here, we investigated the mitochondrial mechanisms affected upon NEF exposure and whether these might be linked to drug hepatotoxicity, in order to infer liabilities of future drug candidates.

Two moderately hepatotoxic NEF concentrations $(20$ and $50 \mu \mathrm{M})$ were selected from dose-response growth curves performed in HepG2 cells. Cell viability, caspase activity, nuclear morphology, mitochondrial transmembrane potential, mitochondrial superoxide levels, and the expression of genes associated with different cellular pathways were evaluated at different time points.

NEF treatment led to an increase in the expression of genes associated with DNA-damage response, antioxidant defense and apoptosis and a decreased expression of genes encoding proteins involved in oxidative phosphorylation, DNA repair, cell proliferation and cell cycle progression, which seem to constitute mechanisms underlying the observed mitochondrial and cell function impairment.
\end{abstract}

() 2016 Elsevier Ltd. All rights reserved.

\section{Introduction}

Nefazodone (NEF) is a phenylpiperazine derivative that belongs to the antidepressant class of serotonin noradrenergic re-uptake inhibitors (SNaRIs), approved in 1994 in the U.S.A (von Moltke et al., 1999). as an alternative to avoid the unwanted side effects associated with the use of other antidepressants, including insomnia, nausea, sedation, cardiovascular toxicity or weight gain (Horst and Preskorn, 1998; Kent, 2000). Despite its efficacy in the treatment of depression, NEF was shown to be toxic, and four cases of hepatic injury were reported in NEF-treated patients in 1999 (Aranda-Michel et al., 1999; Lucena et al., 1999). Later, Bristol-Myers Squibb decided to stop marketing the drug in the U.S.A. due to the

\footnotetext{
* Corresponding author. CNC - Center for Neuroscience and Cell Biology, University of Coimbra, UC Biotech Building, Lot 8A, Biocant Park, 3060-197 Cantanhede, Portugal.

E-mail addresses: mteroliv@cnc.uc.pt, teresa.oliveira@uc-biotech.pt (T. CunhaOliveira).
}

emergence of several hepatotoxicity cases following depression treatment (Aranda-Michel et al., 1999; Choi, 2003; Eloubeidi et al., 2000). As a consequence of NEF treatment, hepatotoxic symptoms were common and included jaundice, dark urine, clay colored stool and increased plasma levels of alanine aminotransferase (ALT), aspartate aminotransferase (AST), total bilirubin and prothrombin time (Aranda-Michel et al., 1999; Lucena et al., 1999). NEF hepatotoxic effects have been previously associated with the inhibition of cytochrome P450 3A4 (CYP3A4), since NEF treatment in human hepatocytes and human liver microsomes in the presence of the non-selective inhibitor of P450, 1-aminobenzotriazole (ABT), resulted in a significant decrease in protein synthesis together with a decrease in NEF metabolism (Kostrubsky et al., 2006). The same work showed that NEF treatment resulted in inhibition of both bile acid transport, via the bile salt export pump (BSEP) present in membrane vesicles, and the canalicular transport in cultured human hepatocytes (Kostrubsky et al., 2006).

NEF was also shown to directly impair hepatic mitochondrial function through inhibition of OXPHOS complexes, particularly 


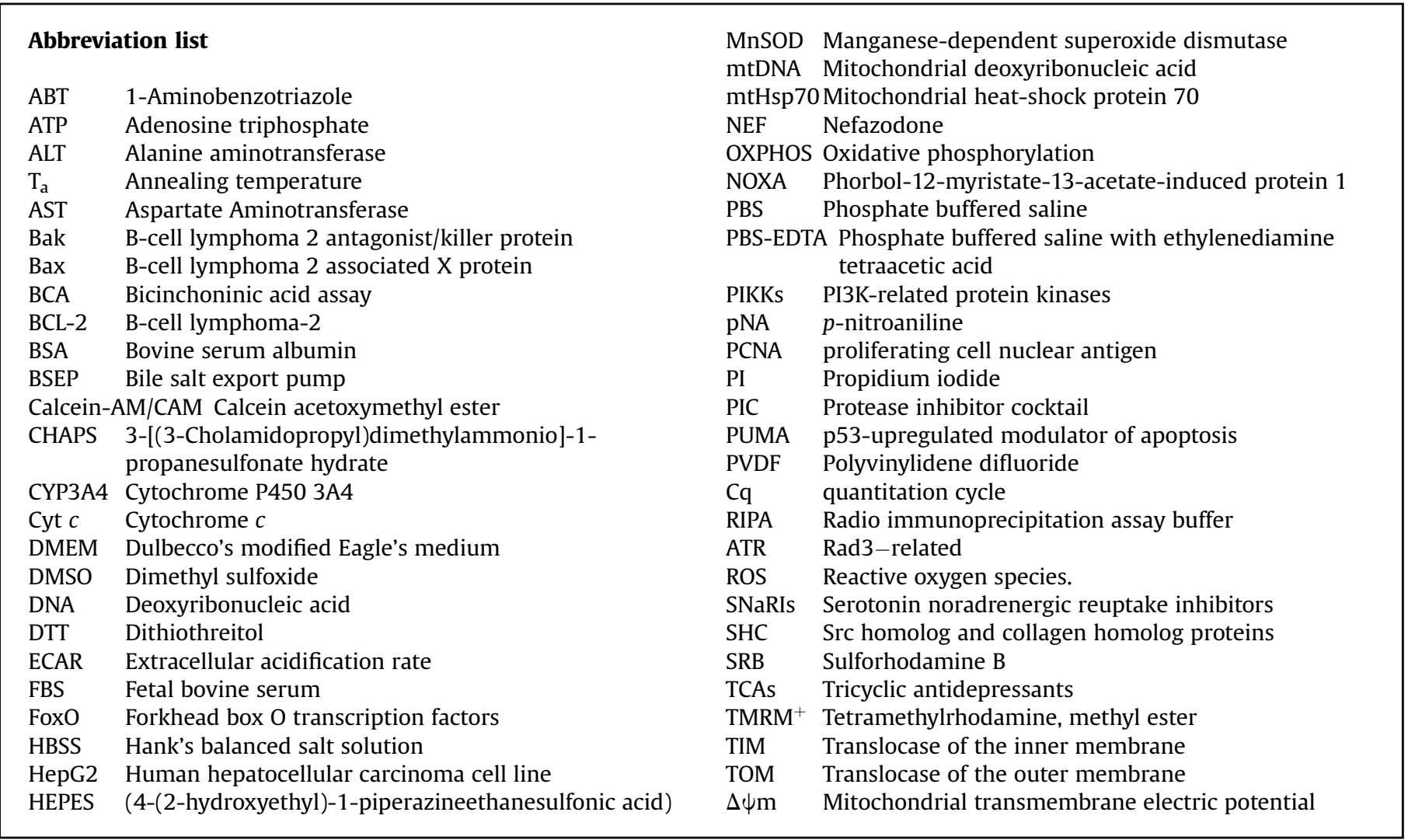

complex I (Dykens et al., 2008; Nadanaciva et al., 2007). Although mitochondrial dysfunction seems to be a major player behind NEF hepatotoxicity, there are only a few reports describing the possible mechanisms involved (Dykens et al., 2008; Kim et al., 2012; Swiss et al., 2013; Xu et al., 2008). Dykens et al., reported that NEF treatment resulted in a decreased mitochondrial transmembrane electric potential $\left(\Delta \Psi_{\mathrm{m}}\right)$, a marked reduction in the intracellular levels of reduced glutathione, and a rise in the levels of reactive oxygen species (ROS) in primary cultures of human hepatocytes (Dykens et al., 2008). A dramatic reduction in oxygen consumption by isolated rat liver mitochondria incubated with NEF was also observed in the same study, followed by an increase in the extracellular acidification rate (ECAR) (Dykens et al., 2008). Further evidence regarding mitochondrial involvement in the reported NEF toxicity came from observation of depleted ATP levels in HepG2 cells upon NEF treatment (Dykens et al., 2008).

Considering the mitochondrial role in the regulation and amplification of apoptotic signaling pathways (Vega-Naredo et al., 2015), NEF-induced mitochondrial dysfunction may be associated with activation of cell death pathways. The main objective of the present work was to characterize NEF hepatotoxic mechanisms on a hepatocyte-like cell, the human hepatocellular carcinoma (HepG2) cell line, with focus on mitochondria-associated pathways commonly associated with drug cytotoxicity, which may be used to predict liabilities of future drug candidates. The HepG2 cell line has been extensively used as a preclinical model to assess drug safety. Despite their lack of xenobiotic metabolic capacity, altered bioenergetic phenotype and lack of polarization, which would in theory covert HepG2 cells into a poor model to study drug hepatotoxicity, the tumorigenic bioenergetic phenotype of HepG2 cells may be an advantage over primary hepatocytes since the Warburg effect confers cancer cells the additional ability to obtain ATP from glycolysis, which may be relevant to drug hepatotoxicity (Kamalian et al., 2015).

\section{Materials and methods}

\subsection{Reagents}

Fetal Bovine Serum (FBS), trypsin-EDTA, Penicillin-Streptomycin-Amphotericin $B$, tetramethylrhodamine methyl ester $\left(\mathrm{TMRM}^{+}\right)$, MitoSOX Red, calcein acetoxymethyl ester (Calcein-AM, or CAM), and Propidium Iodide (PI), were purchased from Invitrogen (Carlsbad, CA, USA). Dulbecco's Modified Eagle's Medium (DMEM)- high glucose (D5648) and DMEM without glucose (D5030), radio immunoprecipitation assay (RIPA) buffer, DLdithiothreitol (DTT), protease inhibitor cocktail (PIC), phosphatase inhibitor cocktail 2, pNA, Ponceau S, Bradford Reagent, NEF, dimethyl sulfoxide (DMSO), sulforhodamine B (SRB) reagent and Hoechst 33342 were obtained from Sigma-Aldrich (St. Louis, MO, USA). Pierce BCA assay kit was purchased from ThermoFisher Scientific (Lafayette, CO, USA). The molecular weight standard (Catalog\# MB09002) was purchased from NZYTech (Lisbon, Portugal). BSA used as a blotting-grade blocker and 2x Laemmli Sample Buffer were purchased from Bio-Rad (Hercules, CA, USA). Caspases-3 and -9 substrates were purchased from Calbiochem (San Diego, CA, USA). All other reagents and chemical compounds used were of the highest degree of purity commercially available.

\subsection{Cell culture and treatments}

The HepG2 cell line was kindly provided by Dr. Carlos Palmeira (Center for Neuroscience and Cell Biology, University of Coimbra). Cells were cultured in high glucose DMEM supplemented with $10 \%$ 
fetal bovine serum, $1 \mathrm{mM}$ sodium pyruvate, $1.8 \mathrm{~g} / \mathrm{L}$ sodium bicarbonate and $1 \%$ penicillin-streptomycin-amphotericin $\mathrm{B}$, in $60 \mathrm{~cm}^{2}$ tissue culture dishes at $37{ }^{\circ} \mathrm{C}$ in a humidified atmosphere of $5 \% \mathrm{CO}_{2}$. For some assays, cells were also cultured in OXPHOS medium, consisting of DMEM supplemented with $6 \mathrm{mM}$ glutamine, $5 \mathrm{mM}$ HEPES, $10 \mathrm{mM}$ galactose, $44 \mathrm{mM}$ sodium bicarbonate, $1 \mathrm{mM}$ sodium pyruvate, $10 \%$ fetal bovine serum and $1 \%$ penicillin-streptomycinamphotericin B. To adapt HepG2 cells to grow in the OXPHOS medium the glucose concentration in the medium was gradually decreased in 25\% steps, for 3 passages, by mixing OXPHOS medium with glucose-containing DMEM. The cells were passed in $100 \%$ OXPHOS medium at least 3 times before any experiments were performed (Swiss and Will, 2011).Where indicated, cells were treated with NEF prepared in DMSO, which was kept refrigerated as a stock solution at $19.7 \mathrm{mM}$ up to 1 month after preparation.

\subsection{Analysis of NEF cytotoxicity by the SRB assay}

The sulforhodamine B colorimetric assay allows the determination of cell density and is based on the measurement of cellular protein content (Vichai and Kirtikara, 2006). HepG2 cells were seeded in 48 well plates at a density of $2 \times 10^{4}$ cells/well. After $24 \mathrm{~h}$, culture medium was replaced and NEF was added in the following concentrations: $5,10,20,50$ and $100 \mu \mathrm{M}$. Cells were further cultured for $0,6,24,48$ or $72 \mathrm{~h}$. A control was performed with DMSO at the highest concentration used in NEF conditions (always less than $0.1 \% \mathrm{v} / \mathrm{v}$ ). At the end of the treatment, the medium was removed, and cells were fixed in $1 \%$ acetic acid in ice-cold methanol, at $-20^{\circ} \mathrm{C}$, for at least $24 \mathrm{~h}$. Cells were then incubated with $0.05 \%$ (wt $/ \mathrm{vol}$ ) SRB in $1 \%$ of acetic acid in water for $1 \mathrm{~h}$ at $37^{\circ} \mathrm{C}$. After the incubation period, the unbound dye was removed with $1 \%$ acetic acid solution. To solubilize the dye bound to cellular proteins, a solution of Tris base $10 \mathrm{mM}, \mathrm{pH} 10$, was used. The optical density of the solution was determined at $545 \mathrm{~nm}$, in a VICTOR X3 multiplate reader (Perkin Elmer Inc.). Doubling times were calculated plotting SRB absorbance versus time, and fitting an exponential curve.

\subsection{Analysis of cell viability by flow cytometry}

Cell viability was assessed in HepG2 cells by flow cytometry, following CAM and PI staining. CAM passively crosses cell membrane and, on viable cells, is converted by intracellular esterases into a green fluorescent form (calcein), being commonly used to stain viable cells. Propidium iodide only permeates through damaged cell membranes and intercalates with DNA, displaying red fluorescence only on permeabilized cells. To perform the assay, cells were seeded on $20 \mathrm{~cm}^{2}$ plates, at a density of $5.7 \times 10^{5}$ cells/ dish. Cells were treated with 20 or $50 \mu \mathrm{M}$ NEF for 48 or $72 \mathrm{~h}$. Once the treatments were finished, cells were trypsinized, centrifuged at $300 \times g$ for $3 \mathrm{~min}$ and incubated with a mixture of CAM $(0.1 \mu \mathrm{M})$ and PI $(7.95 \mu \mathrm{M})$, prepared in Hanks Balanced Saline Solution (HBSS: $5.36 \mathrm{mM} \mathrm{KCl}, 0.6 \mathrm{mM} \mathrm{Na}_{2} \mathrm{HPO}_{4}, 0.44 \mathrm{mM} \mathrm{KH} \mathrm{PO}_{4}, 4.16 \mathrm{mM}$ $\mathrm{NaHCO}_{3}, 2.59 \mathrm{mM} \mathrm{CaCl} 2 \cdot 2 \mathrm{H}_{2} \mathrm{O}, 0.49 \mathrm{mM} \mathrm{MgCl} \cdot 6 \mathrm{H}_{2} \mathrm{O}, 1.19 \mathrm{mM}$ $\mathrm{MgSO}_{4}, 137.9 \mathrm{mM} \mathrm{NaCl}, 5.55 \mathrm{mM}$ D-glucose). Incubation was performed for 15-20 min, protected from light, at room temperature. The fluorescence of both probes was quantified through flow cytometry after running 20,000 cells at a medium/high sample flow rate on a FACSCalibur flow cytometer (BD Biosciences, San Jose, California, USA).

\subsection{Analysis of caspases 9 and 3-like activities}

To evaluate caspase 9 and 3-like activities, cells were seeded in $60 \mathrm{~cm}^{2}$ dishes at a density of $1.7 \times 10^{6}$ cells/dish. Cells were treated with 20 or $50 \mu \mathrm{M}$ NEF for 24 or $48 \mathrm{~h}$, and at the end of treatment, both floating and adherent cells were collected. The culture medium in the dishes was centrifuged twice at $1000 \times \mathrm{g}$ for $5 \mathrm{~min}$, and cell pellets were resuspended in assay buffer (50 mM HEPES pH 7.4; $100 \mathrm{mM} \mathrm{NaCl}$; 0.1\% CHAPS; 10\% glycerol; $10 \mathrm{mM} \mathrm{DTT).} \mathrm{Adherent}$ cells were washed with PBS $(0.137 \mathrm{M} \mathrm{NaCl}, 2.7 \mathrm{mM} \mathrm{KCl}, 1.4 \mathrm{mM}$ $\mathrm{KH}_{2} \mathrm{PO}_{4}, 0.01 \mathrm{M} \mathrm{Na}_{2} \mathrm{HPO}_{4}$ ) and total cellular extracts were harvested by scraping the attached cells in assay buffer. Floating and adherent cells were then combined and cell lysis was performed through three cycles of freeze/thaw with liquid nitrogen/water bath at room temperature, and samples were then passed through a 27G needle (20-30 strokes). Cellular extracts were centrifuged at $14,000 \times \mathrm{g}$ for $5 \mathrm{~min}$ and supernatants were transferred to new tubes. Protein content of each sample was determined using the Bradford assay (Bradford, 1976), using BSA as a standard. To measure caspase 3 and 9-like activities, aliquots of cell extracts containing $25 \mu \mathrm{g}$ or $50 \mu \mathrm{g}$ of protein, respectively, were incubated for two hours at $37^{\circ} \mathrm{C}$ with $100 \mu \mathrm{M}$ substrate solutions containing AcDEVD-pNA, for caspase-3-like activity, or Ac-LEHD-pNA, for caspase-9-like activity. After the incubation period, the absorbance of pNA resulting from substrate cleavage by caspases was read at $405 \mathrm{~nm}$ in a Spectramax Plus 384 microplate reader (Molecular Devices, Silicon Valley, CA, USA). The assay was calibrated with known concentrations of pNA, and the results were expressed as \% pNA released.

\subsection{Confocal microscopy}

The effect of NEF on mitochondrial superoxide anion generation, $\Delta \Psi_{\mathrm{m}}$, cell mass and nuclear morphology was evaluated through confocal microscopy, using the probes MitoSOX Red, $\mathrm{TMRM}^{+}$or Hoechst 33342, respectively. Cells were seeded on $60 \mathrm{~cm}^{2}$ dishes, at a density of $1.7 \times 10^{6} /$ dish and treated with 20 or $50 \mu \mathrm{M}$ NEF. After the first $24 \mathrm{~h}$ of treatment, cells were trypsinized, centrifuged at $300 \times g$ for $3 \mathrm{~min}$, resuspended in culture medium containing NEF at the respective concentration, and transferred to $\mu$-Slide 8 well ibiTreat (Ibidi Martinsried, Germany) at a density of 50,000 cells/ well. Treatment conditions were kept after transfer. At the end of treatment ( $48 \mathrm{~h}$ or $72 \mathrm{~h}$ ), culture medium was removed and cells were incubated with either a mixture of $\mathrm{TMRM}^{+}(150 \mathrm{nM})$ plus Hoechst $33342(1 \mu \mathrm{g} / \mathrm{ml})$ probes or with a mixture of Hoechst $33342(1 \mu \mathrm{g} / \mathrm{ml})$ plus MitoSOX Red mitochondrial superoxide indicator $(5 \mu \mathrm{M})$, prepared in HBSS. Incubation was performed at $37^{\circ} \mathrm{C}$ for $30 \mathrm{~min}$, in the dark. Cells were observed under a Zeiss LSM 510Meta confocal microscope and images were obtained through LSM Image Browser. Image acquisition and image analysis was performed at the MICC Imaging facility of CNC.

\subsection{Analysis of gene expression by quantitative real-time $P C R$}

Total RNA was extracted with Aurum ${ }^{\mathrm{TM}}$ Total RNA Mini Kit (BioRad, Hercules, CA, USA), following the manufacturer's protocol, and quantified using a Nanodrop 2000 (ThermoScientific, Waltham, MA, USA), confirming that A260/280 was always higher than 1.9. RNA integrity was verified by Experion RNA StdSens kit (Bio-Rad), and RNA was converted into cDNA using the iScript ${ }^{\mathrm{TM}}$ cDNA Synthesis Kit (Bio-Rad), following the manufacturer's instructions. RTPCR was performed using the SsoFast Eva Green Supermix, in a CFX96 real time-PCR system (Bio-Rad), with the primers defined in Table 1, at $500 \mathrm{nM}$. Amplification of $25 \mathrm{ng}$ was performed with an initial cycle of $30 \mathrm{~s}$ at $95.0^{\circ} \mathrm{C}$, followed by 40 cycles of $5 \mathrm{~s}$ at $95^{\circ} \mathrm{C}$ plus $5 \mathrm{~s}$ at the annealing temperature $\left(\mathrm{T}_{\mathrm{a}}\right)$ shown in Table 1 . At the end of each cycle, Eva Green fluorescence was recorded to enable determination of Cq. After amplification, melting temperatures of the PCR products were determined by performing melting curves. 
Table 1

Sequences of primers used for the analysis of gene expression.

\begin{tabular}{|c|c|c|c|c|}
\hline Gene & Accession number & Forward primer & Reverse primer & $\mathrm{T}_{\mathrm{a}}\left({ }^{\circ} \mathrm{C}\right)$ \\
\hline ATP 8 & NC_012920 (8366-8572) & АСТАССАССТАССТСССТСАС & GGATTGTGGGGGCAATGAATG & 59 \\
\hline ATR & NM_001184 & TCCCTTGAATACAGTGGCCTA & TCCTTGAAAGTACGGCAGTTC & 59 \\
\hline $\operatorname{COXI}$ & NC_012920 (5904-7445) & ATACCAAACGCCCCTCTTCG & TGTTGAGGTTGCGGTCTGTT & 61 \\
\hline FOS & NM_005252 & GGGGCAAGGTGGAACAGTTAT & AGGTTGGCAATCTCGGTCTG & 63 \\
\hline FOXO3 & NM_001455 & GAGTCCATTATCCGTAGTGAAC & CAGTTTGAGGGTCTGCTTTG & 61 \\
\hline JUN & NM_002228 & ACGTTAACAGTGGGTGCCAA & TCTCTCCGTCGCAACTTGTC & 61 \\
\hline ND5 & NC_012920 (12337-14148) & AGTTACAATCGGCATCAACCAA & CCCGGAGCACATAAATAGTATGG & 59 \\
\hline NOXA & NM_021127 & GCAAGAACGCTCAACCGAG & TTTGAAGGAGTCCCCTCATGC & 63 \\
\hline PCNA & NM_002592 & GAAGCACCAAACCAGGAGAAAG & GCACAGGAAATTACAACAGCATCT & 59 \\
\hline PUM1 & NM_014676 & GCAAAGATGGACCAAAAGGA & ATTGGCTGGGAAACTGAATG & 59 \\
\hline PUMA & NM_014417 & GGACGACCTCAACGCACAGT & TGAGATTGTACAGGACCCTCCA & 63 \\
\hline YWHAZ & NM_003406 & TGTAGGAGCCCGTAGGTCATC & GTGAAGCATTGGGGATCAAGA & 61 \\
\hline
\end{tabular}

For each set of primers, amplification efficiency was assessed, and no template and no transcriptase controls were run. Relative normalized expression was determined using the CFX96 Manager software (v. 3.0; Bio-Rad), with PUM1 and YWHAZ as reference genes, considered together.

\subsection{Statistical analysis}

Data were expressed as mean \pm SEM for the number of experiments indicated in the figure legends. Grouped comparisons were performed using two-way analysis of variance (ANOVA). Multiple comparisons were performed using one-way ANOVA followed by Bonferroni post-hoc test. Significance was accepted with $p$ value $<0.05$

\section{Results}

\subsection{Characterization of NEF impact on HepG2 cell viability}

To investigate the effect of NEF on HepG2 cell mass, cells were exposed to NEF concentrations ranging from 0 to $100 \mu \mathrm{M}$ at different exposure times ( $0-72 \mathrm{~h}$ ), and cell mass was evaluated by the SRB assay (Fig. 1A). The results show that the lowest NEF concentrations tested ( 5 and $10 \mu \mathrm{M}$ ) did not significantly affect cell mass at any of the exposure times tested. After $24 \mathrm{~h}$ of treatment, only cells exposed to the highest NEF concentration $(100 \mu \mathrm{M})$ presented a significant decrease on cell mass comparatively to cells in the control group. A significant decrease on cell mass was also observed when cells were treated with $20-100 \mu \mathrm{M}$ NEF for $48 \mathrm{~h}$ and $72 \mathrm{~h}$. At the latter time point, treatment with NEF at a $10 \mu \mathrm{M}$ concentration also elicited a significant decrease on cell mass, comparatively to the control group. At concentrations of $20 \mu \mathrm{M}$ or higher, NEF seemed to block cell proliferation and induce cell death. For 5 and $10 \mu \mathrm{M}$ NEF the doubling times (32.2 and $45.53 \mathrm{~h}$, respectively) were increased in comparison with cells treated with DMSO alone (27.1 h), also suggesting impairment of cell proliferation. At higher concentrations NEF completely blocked cell proliferation.

For follow-up studies, we selected two drug concentrations that did not affect cell mass upon $24 \mathrm{~h}$ of treatment, but exhibited different degrees of toxicity for longer exposure periods, in order to uncover biological effects of an acute treatment with this drug.

To evaluate the impact of NEF treatment on cell viability, HepG2 cells were incubated with the fluorescent probes CAM and PI, and analyzed by flow cytometry (Fig. 1B,C). CAM passively crosses cell membrane and, in viable cells, is converted by intracellular esterases into a green fluorescent form (calcein). Propidium iodide only permeates through damaged cell membranes and intercalates with DNA, displaying red fluorescence only in permeabilized cells.
Quadrants containing positive cells for only one of the dyes were considered either dead cells (detected on quadrant 1: CAM negative/PI positive), or live cells (detected on quadrant 4: CAM positive/ PI negative). Cells presenting both types of fluorescence (quadrant 2: CAM positive/PI positive) were considered permeabilized cells, presenting both damaged plasma membranes and active intracellular metabolism.

A significant increase in the permeabilized cell population and a corresponding decrease in the live cell population were only observed for $50 \mu \mathrm{M}$ NEF, at 48 and $72 \mathrm{~h}$. At $72 \mathrm{~h}$ a decrease in dead cells was also observed in cells incubated with $50 \mu \mathrm{M}$ NEF.

The effect of NEF on caspases -3 and -9 -like activities was evaluated by following the cleavage of the colorimetric substrates Ac-DEVD-pNA and Ac-LEHD-pNA, respectively (Fig. 1 D,E). The results showed an increase in caspase-9-like activity in cells treated with $20 \mu \mathrm{M}$ NEF at 24 and $48 \mathrm{~h}$, and an increase in caspase-3-like activity at $48 \mathrm{~h}$. These observations suggest the activation of the mitochondrial apoptotic pathway. Interestingly, no significant changes were found in the activity of the analyzed caspases for cells treated with $50 \mu \mathrm{M}$ NEF.

\subsection{NEF induced changes on nuclear morphology and mitochondrial membrane potential}

To assess alterations on nuclear morphology as well as alterations on mitochondrial membrane potential, cells treated with 20 and $50 \mu \mathrm{M}$ NEF for 48 or $72 \mathrm{~h}$ and controls were labeled with Hoechst 33342 and $\mathrm{TMRM}^{+}$and visualized by confocal microscopy (Fig. 2).

Confocal images revealed a decrease in cell number after treatment with $20 \mu \mathrm{M}$ and $50 \mu \mathrm{M}$ NEF for 48 and $72 \mathrm{~h}$, when compared with the control, with a more significant effect for the highest NEF concentration.

Labeling with Hoechst 33342, allowed to visualize changes in nuclear morphology in cells treated both NEF concentrations, comparatively to non-treated cells. Cell nuclei exhibited a more irregular shape on cells treated with 20 and $50 \mu \mathrm{M} \mathrm{NEF}$ for $48 \mathrm{~h}$ and $72 \mathrm{~h}$, with more obvious changes in nuclear morphology observed in cells treated with $50 \mu \mathrm{M}$ NEF, for both incubation times. These cells exhibited profound changes in morphology with more rounded and small nuclei, known to characterize apoptotic cells.

NEF effect on mitochondrial membrane potential was analyzed after $\mathrm{TMRM}^{+}$labeling. $\mathrm{TMRM}^{+}$accumulates inside mitochondria depending on the $\Delta \Psi_{\mathrm{m}}$, and polarized mitochondria become labeled with red fluorescence, when $\mathrm{TMRM}^{+}$is used in nonquenching concentrations (Gerencser et al., 2012). Our results showed that after $72 \mathrm{~h}$ of treatment with $20 \mu \mathrm{M}$ NEF cells seemed to present increased $\mathrm{TMRM}^{+}$fluorescence, more evident than that observed after $48 \mathrm{~h}$ of treatment. Treatment with $50 \mu \mathrm{M}$ NEF for 48 
A

\section{Cell mass (glucose medium)}

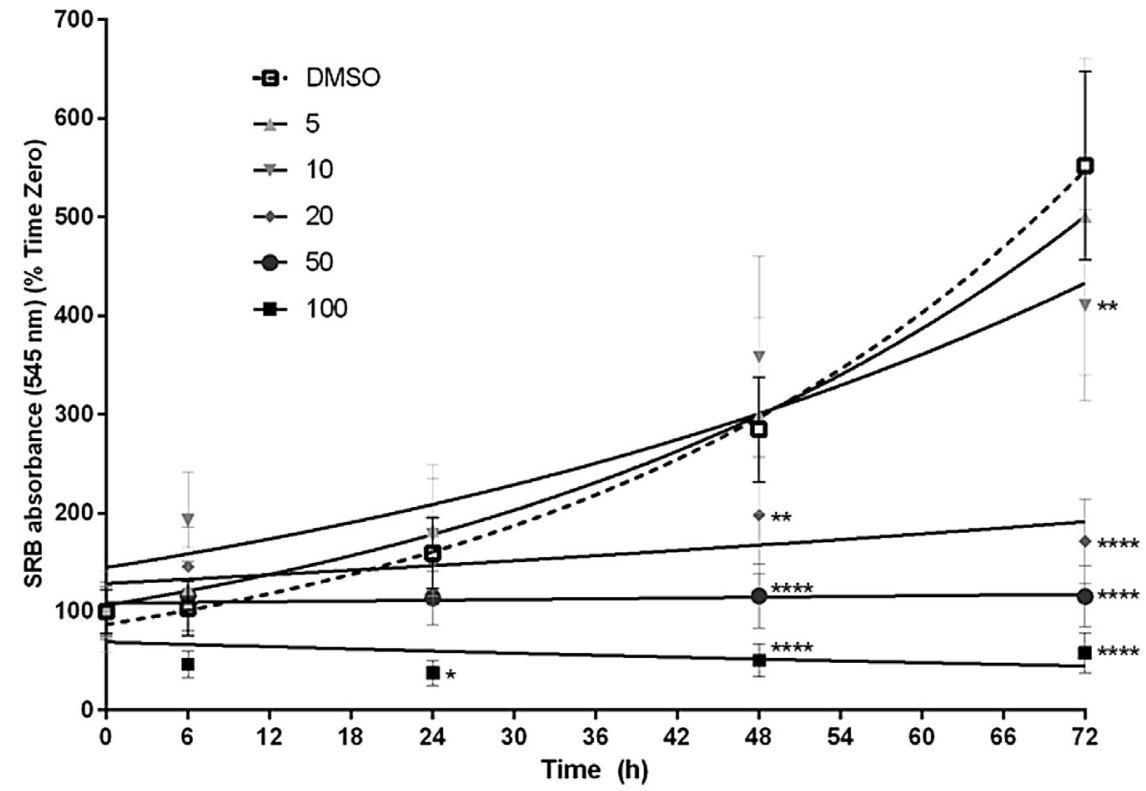

B

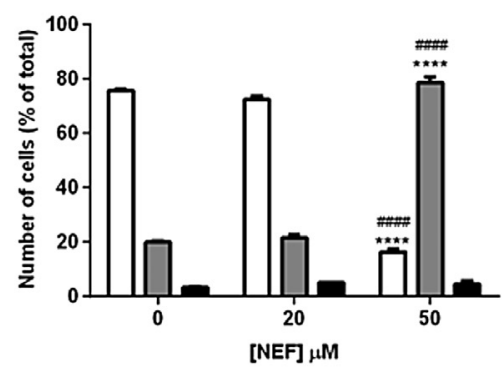

D

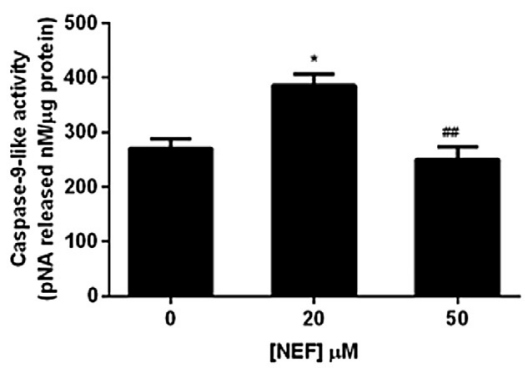

F

$24 \mathrm{~h}$

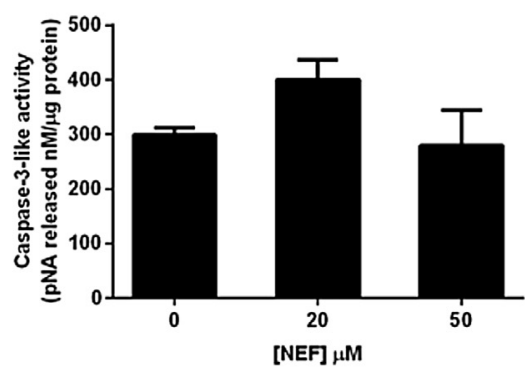

C

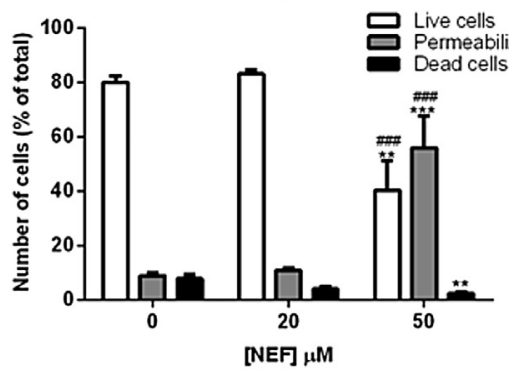

E

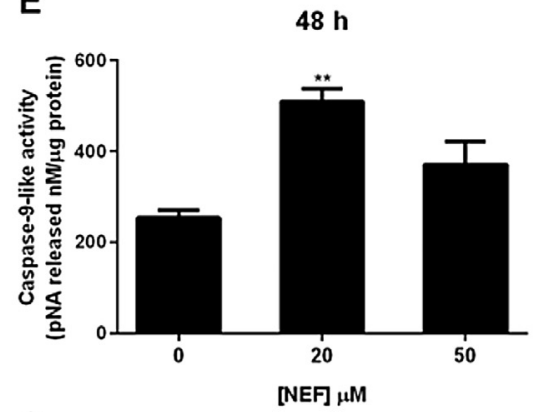

G

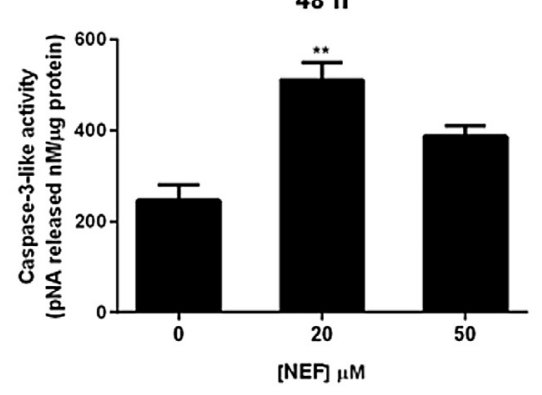

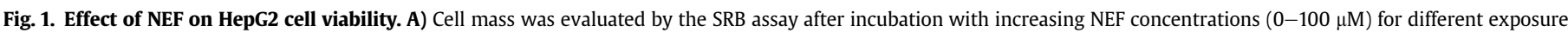

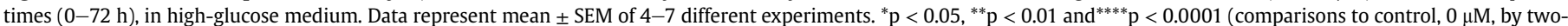

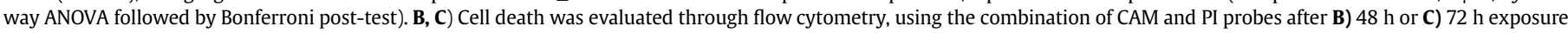

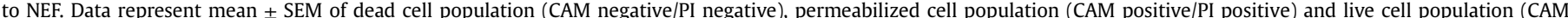

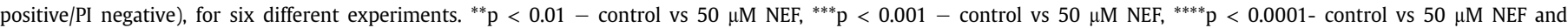

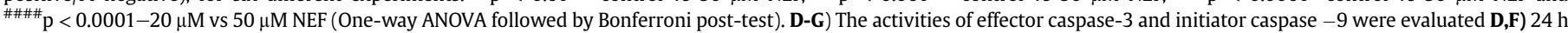

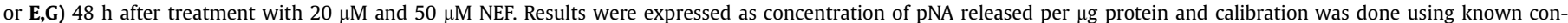

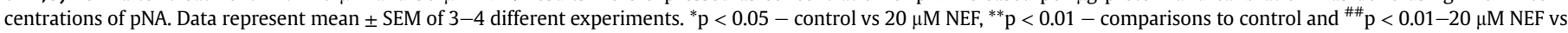
$50 \mu \mathrm{M}$ NEF (One-way ANOVA, followed by Bonferroni post-test). 
A
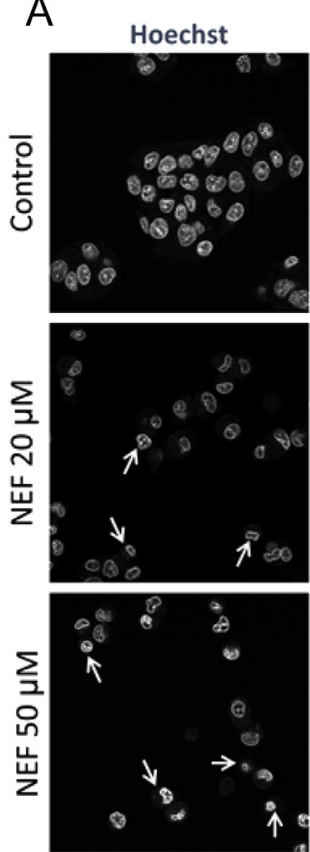

$48 \mathrm{~h}$ TMRM $^{+}$
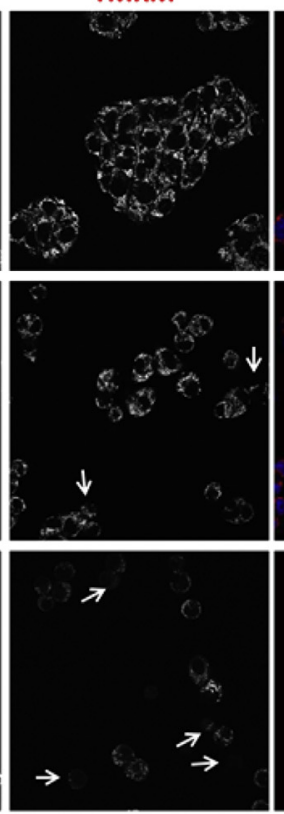

Merge
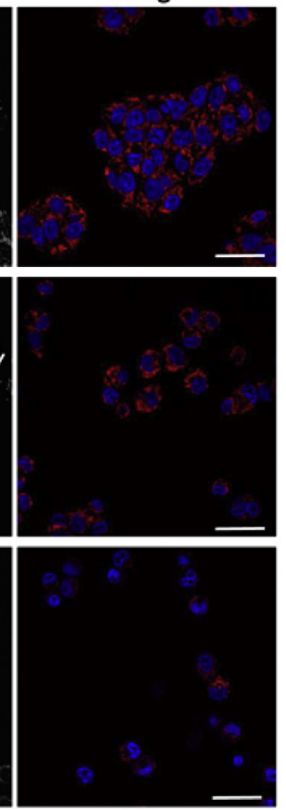

B
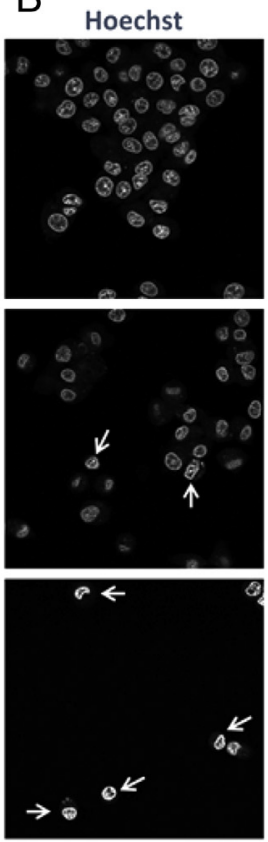

$72 \mathrm{~h}$ TMRM $^{+}$
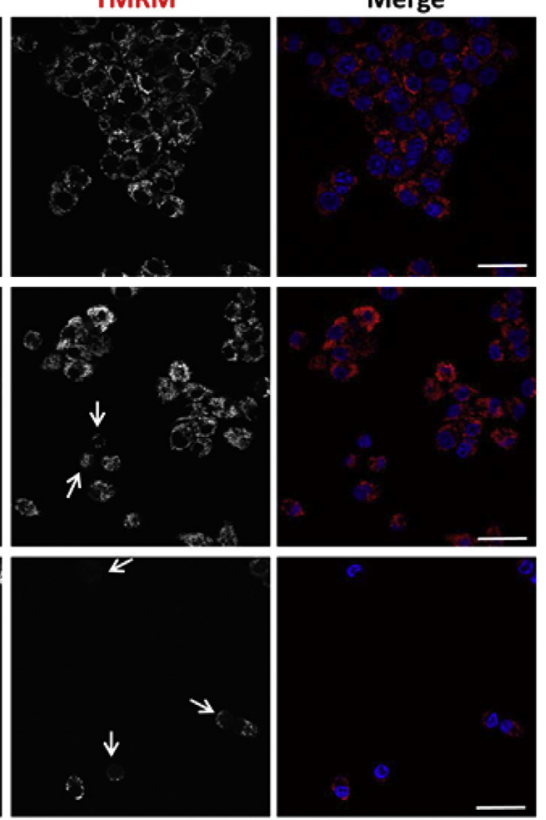

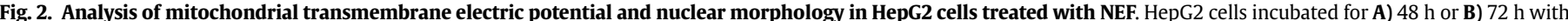

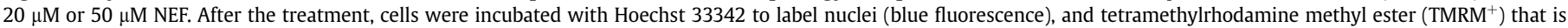

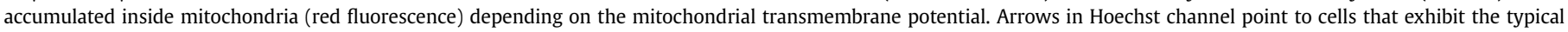

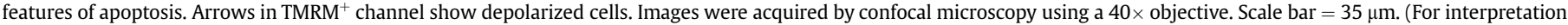
of the references to colour in this figure legend, the reader is referred to the web version of this article.)

or $72 \mathrm{~h}$ induced a decrease on $\mathrm{TMRM}^{+}$fluorescence, comparatively to non-treated cells, indicating a decrease in $\Delta \Psi_{\mathrm{m}}$.

\subsection{NEF treatment increased mitochondrial superoxide anion levels on HepG2 cells}

Considering the above described results, NEF seems to have an effect on mitochondrial membrane potential, as well as on the mitochondrial apoptotic pathway, which may be associated with increased mitochondrial ROS. We then analyzed the levels of mitochondrial superoxide anion by labelling cells with MitoSOX Red, upon treatment with $20 \mu \mathrm{M}$ NEF for $48 \mathrm{~h}$ or $72 \mathrm{~h}$ (Fig. 3A).

MitoSOX fluorescent signal was increased in cells treated with $20 \mu \mathrm{M}$ NEF for 48 or $72 \mathrm{~h}$, when compared to non-treated cells, suggesting an increase on superoxide anion levels. It was not possible to analyze MitoSOX labeling on cells treated with $50 \mu \mathrm{M}$ NEF probably due to the NEF-induced impairment of $\Delta \Psi_{\mathrm{m}}$, which may inhibit the accumulation of MitoSOX in mitochondria.

\subsection{NEF is more toxic in HepG2 cells adapted to rely on OXPHOS}

The role of mitochondria on NEF hepatotoxicity was further evaluated on HepG2 cells adapted to grow in OXPHOS medium, which remodels cell metabolism to rely exclusively on OXPHOS for energy (Marroquin et al., 2007). Under these culture conditions, HepG2 cells were incubated with increasing NEF concentrations for different treatment periods, and cell mass was analyzed by the SRB assay (Fig. 3B). Results show that these cells were more susceptible to NEF toxicity, suffering significant decreases in cell mass at earlier time points and for lower NEF concentrations, compared to HepG2 cells cultured in glucose medium.

Cell mass was significantly decreased $6 \mathrm{~h}$ after treatment with $100 \mu \mathrm{M}$ NEF, comparatively to cells in the control group (DMSO). After $24 \mathrm{~h}$ of treatment, a significant decrease in cell mass was observed for $10-100 \mu \mathrm{M} N E F$, and at 48 or $72 \mathrm{~h}$ of treatment all NEF concentrations tested led to a significant decrease in cell mass. Moreover, $5 \mu \mathrm{M}$ NEF-treated cells showed a doubling time of $57.9 \mathrm{~h}$, whereas for control cells this was of $38.2 \mathrm{~h}$. Overall our results suggest that high concentrations of NEF block cell proliferation.

\subsection{NEF-induced changes in gene expression}

To evaluate possible changes in gene expression induced by NEF, we analyzed the mRNA levels of three different transcription factors involved in cellular response to toxicants (Fig. 4 A-C).

FOXO3 belongs to a family of transcription factors that modulate the expression of genes involved in cell survival and metabolism and in the upregulation of antioxidant defenses (Wang et al., 2014). Treatment with $20 \mu \mathrm{M}$ and $50 \mu \mathrm{M}$ for $24 \mathrm{~h}$ resulted in increased FOXO3 expression, comparatively to control cells.

We also analyzed the mRNA levels of FOS and JUN, which belong to the AP-1 transcription factor family and also play a role in cell death regulation (Angel and Karin, 1991). The results show that treatment with $50 \mu \mathrm{M}$ NEF significantly increased FOS and JUN expression comparatively to control cells, while no significant differences were found on cells treated with $20 \mu \mathrm{M}$ NEF.

Additionally, the expression of two genes that encode NOXA (also known as PMAIP1) and PUMA (also known as BBC3) were analyzed. These are two p53-induced pro-apoptotic proteins from the BH3-only group which mediate apoptotic mitochondrial permeabilization and trigger the intrinsic apoptotic pathway (Khoo et al., 2014) (Fig. 4 D,E).

Treatment with 20 and $50 \mu \mathrm{M}$ NEF significantly increased the levels of NOXA transcripts, in comparison to non-treated cells. The observed increase was higher in cells treated with $50 \mu \mathrm{M}$ NEF when compared to the expression observed after treatment with $20 \mu \mathrm{M}$ NEF.

PUMA expression has been associated with the activation of 

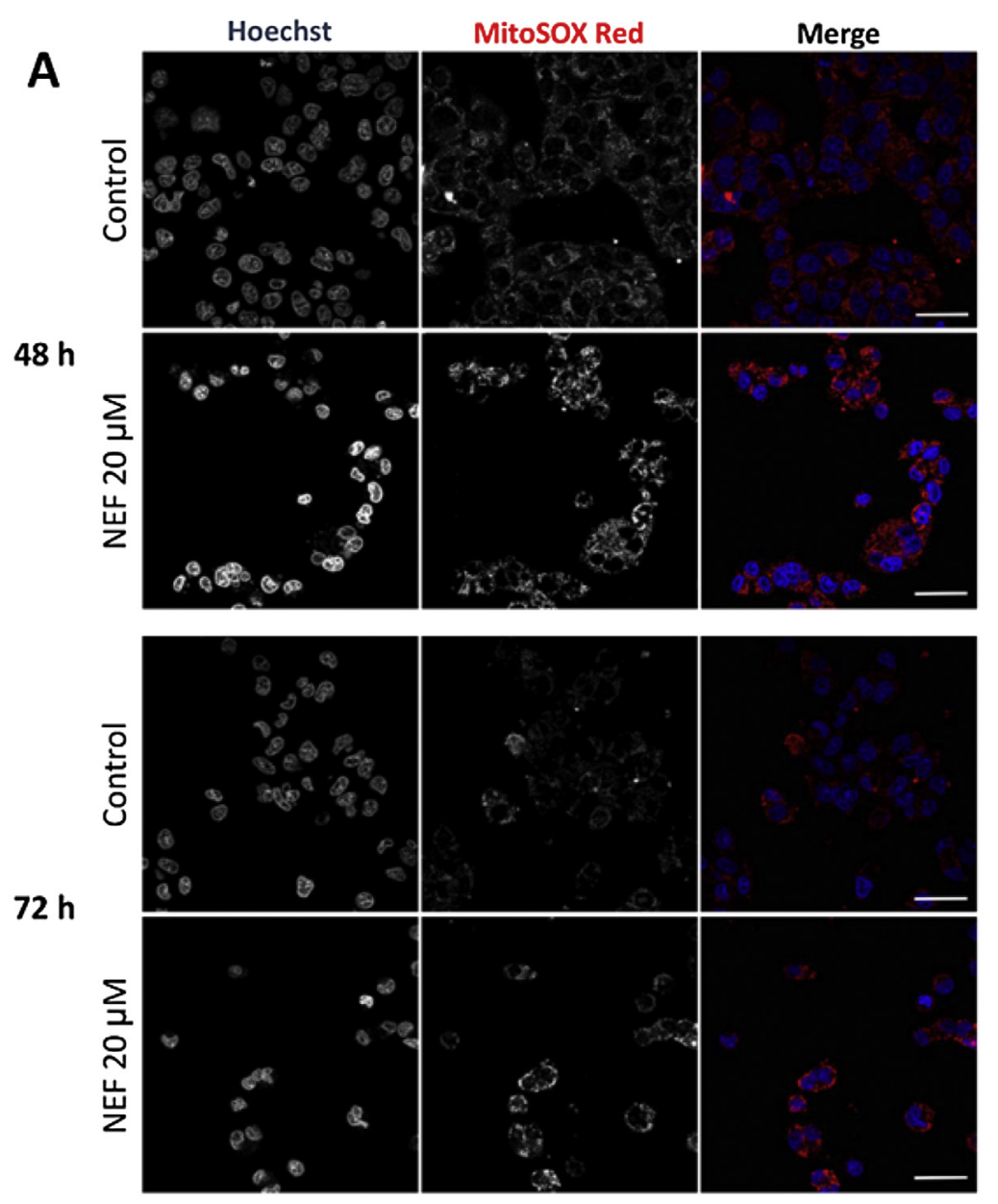

B

\section{Cell mass (OXPHOS medium)}

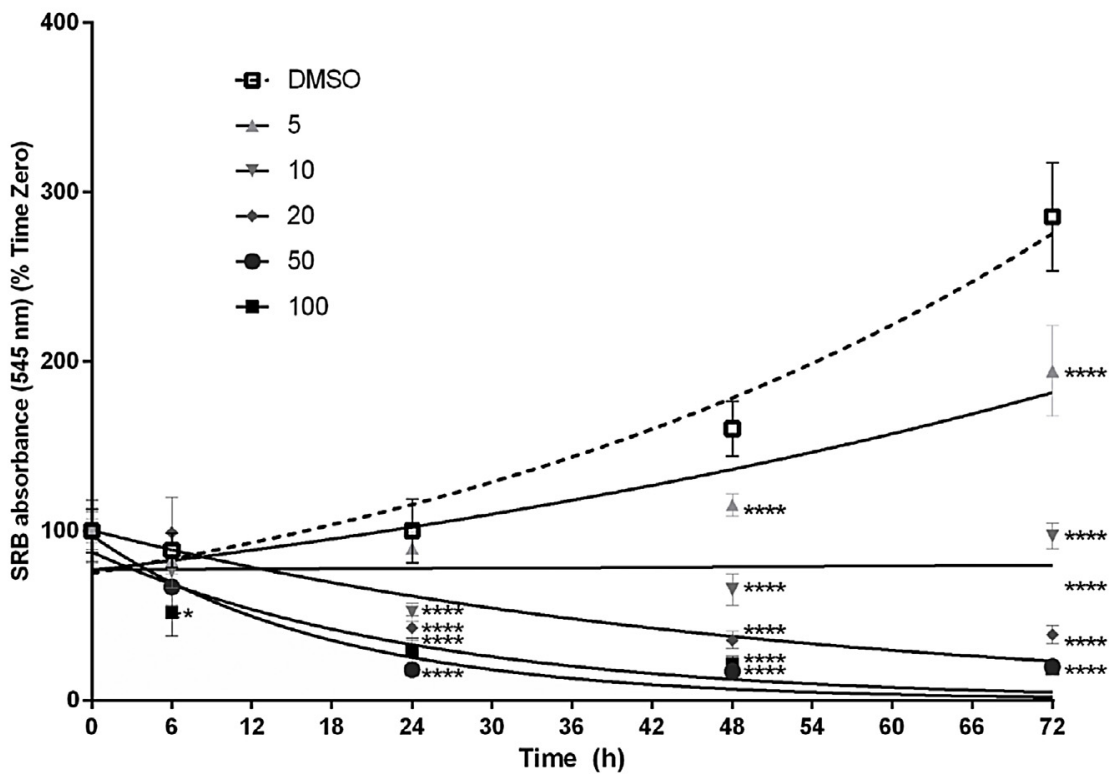

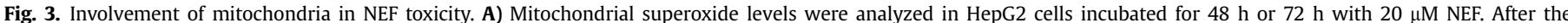

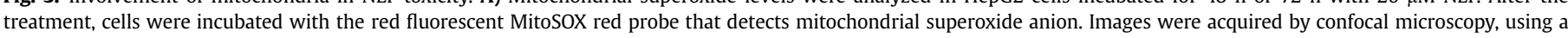

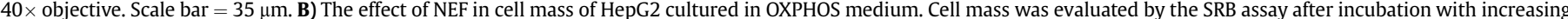

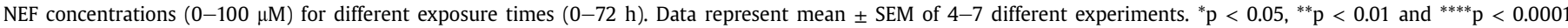

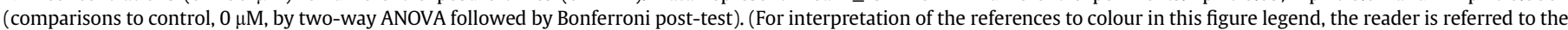
web version of this article.) 
Transcription factors
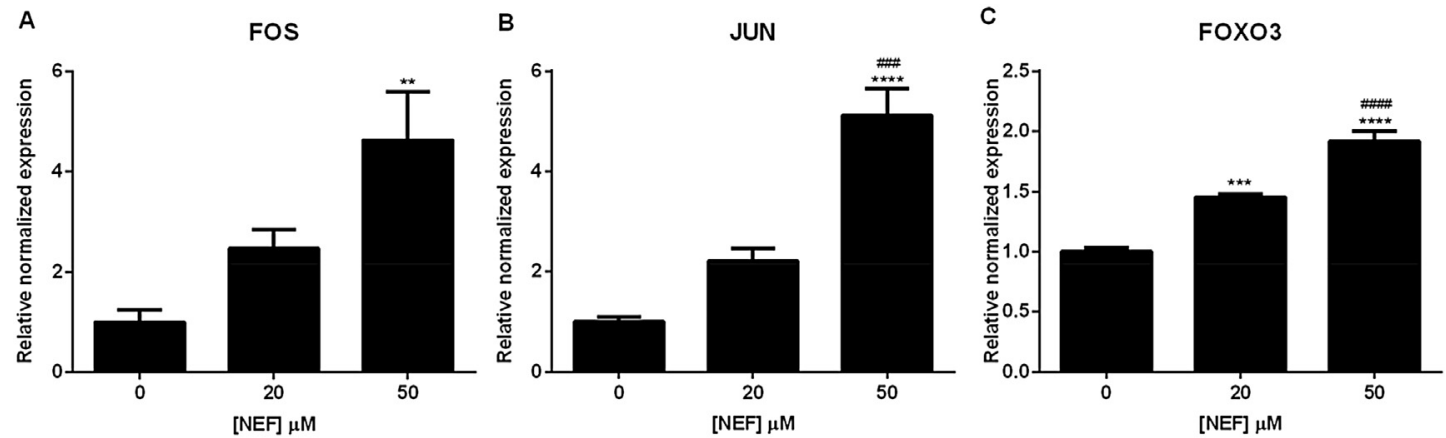

p53-induced apoptotic genes
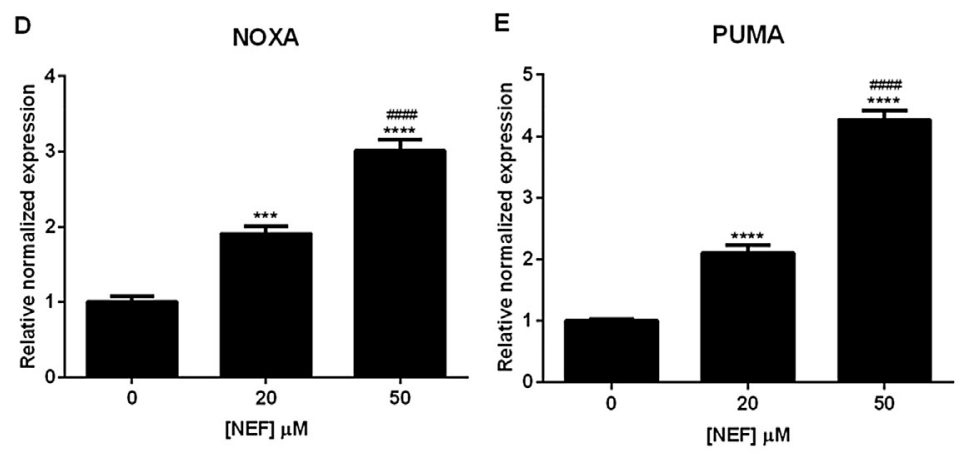

DNA repair-related genes

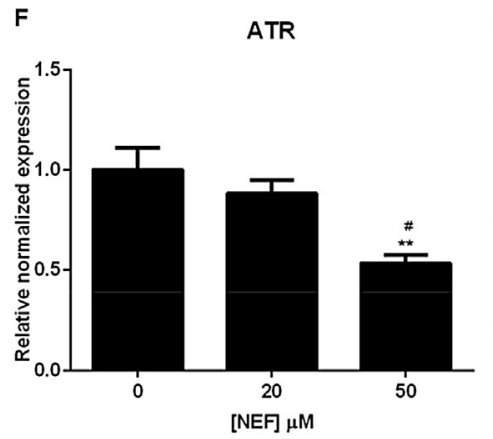

G

PCNA

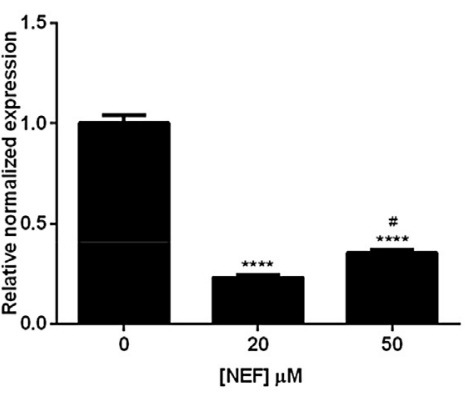

\section{Mitochondrial DNA-encoded genes}
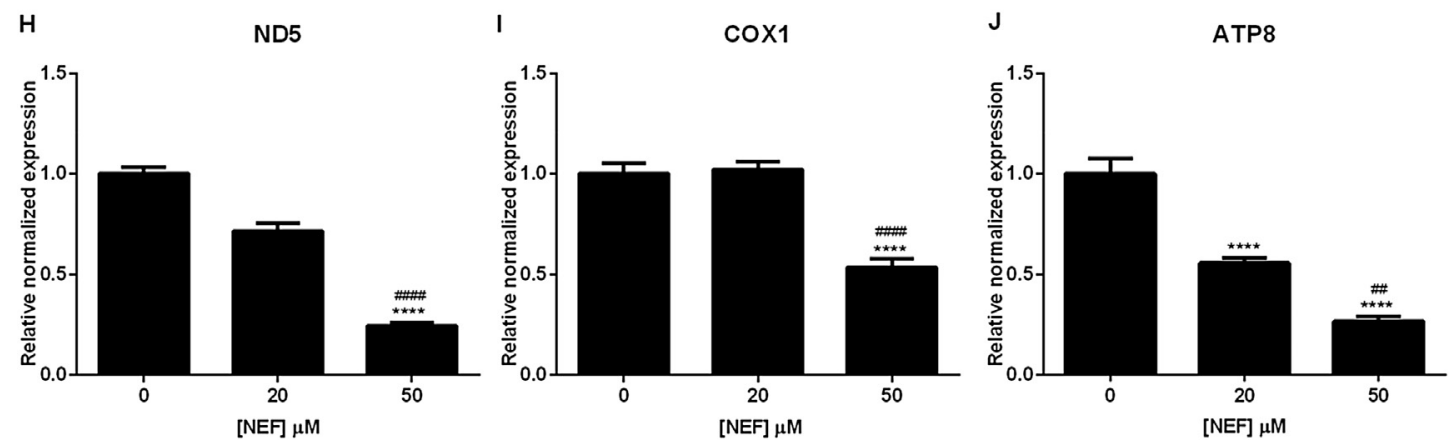

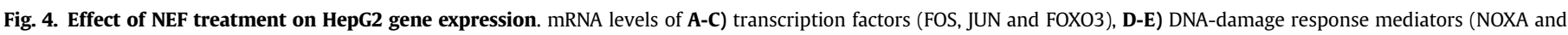

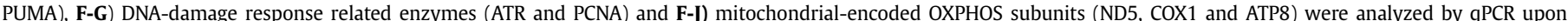

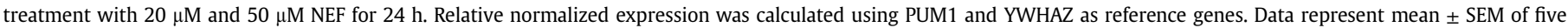

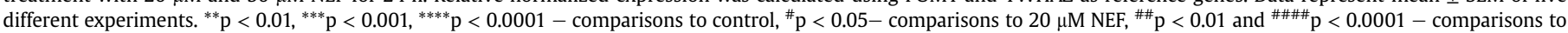
$20 \mu \mathrm{M}$ NEF (One-way ANOVA, followed by Bonferroni post-test). 
p53-dependent apoptosis, followed by growth inhibition, cytochrome $c$ release and activation of caspases -3 and -9 . Treatment with 20 and $50 \mu \mathrm{M}$ NEF for $24 \mathrm{~h}$ increased PUMA expression when compared to control. Moreover, the effect of $50 \mu \mathrm{M}$ NEF on PUMA expression was also significantly higher comparatively to cells treated with $20 \mu \mathrm{M}$ NEF.

The increase in p53-induced genes suggests the occurrence of DNA damage after exposure to NEF. Thus, we analyzed the expression of two genes associated with DNA repair (Christmann and Kaina, 2013) (Fig. 4 F,G). The ATR gene encodes the Rad3related (ATR) protein, a member of the PI3K-related protein kinases (PIKKs) that acts as a primary regulator of the replication stress response. Incubation with $20 \mu \mathrm{M}$ NEF did not induce significant changes in ATR expression, but a significant decrease in ATR mRNA levels was observed in cells exposed to $50 \mu \mathrm{M}$ NEF, comparatively to both non-treated and $20 \mu \mathrm{M}$ NEF-treated cells. We also analyzed the expression of the PCNA gene, which encodes the proliferating cell nuclear antigen (PCNA) protein involved in DNA replication, chromatin remodeling, DNA repair, sister-chromatid cohesion and cell cycle control, with an impact on cell proliferation. Results showed that both concentrations of NEF used $(20 \mu \mathrm{M}$ and $50 \mu \mathrm{M}$ ) led to a decrease in PCNA expression, in agreement with the decrease in proliferation observed with the SRB assay.

Considering NEF effects on mitochondrial function, we investigated whether mitochondrial transcription was affected, by analyzing the levels of three mitochondrial DNA (mtDNA)-encoded transcripts, coding for the respiratory chain subunits ND5, COX1 and ATP8 (Fig. $4 \mathrm{H}, \mathrm{I}$ ).

Treatment with $50 \mu \mathrm{M}$ NEF for $24 \mathrm{~h}$ significantly decreased ND5 and $C O X-1$ gene expression when compared to control. ATP8 gene expression was decreased upon NEF treatment with both concentrations tested (20 and $50 \mu \mathrm{M}$ ), when compared to the control group, although significantly less after treatment with the lower NEF concentration, compared to $50 \mu \mathrm{M}$ NEF.

\section{Discussion}

NEF is an antidepressive agent developed by Bristol-Myers Squibb that was widely used in the treatment of depression until it was withdrawn from the pharmaceutical market due to the emergence of liver injury and failure in several NEF-treated patients (Aranda-Michel et al., 1999).

NEF hepatotoxicity was previously reported to be associated with mitochondrial impairment, due to interference with OXPHOS enzymatic activities (Dykens et al., 2008; Nadanaciva et al., 2007), increased ROS generation and decreased antioxidant defenses (Dykens et al., 2008). However, the mechanisms underlying NEFinduced mitochondrial dysfunction in hepatocytes are not completely understood. The understanding of possible mitochondrial liabilities is of high importance as it might allow the improvement of screening of new drug candidates. In this regard, we investigated NEF impact on mitochondrial mechanisms associated with drug cytotoxicity that could be used to predict liabilities of future drug candidates.

We selected two drug concentrations that did not induce toxicity after $24 \mathrm{~h}$ of treatment and exhibited different degrees of toxicity for longer exposures in HepG2 cells cultured in regular medium containing glucose. Although both concentrations tested $(20 \mu \mathrm{M}$ and $50 \mu \mathrm{M})$ are higher than those found in the plasma of patients treated with NEF (around $1 \mu \mathrm{M}$ (Barbhaiya et al., 1996; Dykens et al., 2008)), the use of these concentrations represents an acute treatment protocol that better enables uncovering of biological effects. Moreover, drugs are frequently accumulated in the liver, becoming several times more concentrated in the hepatic tissue compared to the plasma (Chu et al., 2013). Although data on plasma-to-liver ratio of NEF is not available in the literature, if NEF does accumulate in the liver it could potentially inhibit its own elimination (Dykens et al., 2008; Kostrubsky et al., 2006), contributing to further increases in tissue drug concentration. As our objective was to use NEF as a model hepatotoxic compound withdrawn from the market, to help predict the toxicity of future drug candidates, we had to find an experimental setting where drug toxicity was manifested.

Our results showed that the lower NEF concentration used in this study ( $20 \mu \mathrm{M})$ decreased cell mass to 0.7 times, at $48 \mathrm{~h}$, and 0.31 times, at $72 \mathrm{~h}$, comparatively to cells treated with DMSO alone. After $24 \mathrm{~h}$ of exposure, $20 \mu \mathrm{M}$ NEF treatment induced an increase in the activity of the initiator caspase-9, which persisted at $48 \mathrm{~h}$. At this time point $(48 \mathrm{~h})$, there was also an increase in the activity of the effector caspase-3, suggesting the activation of the mitochondrial apoptotic pathway.

Nuclei of cells treated with $20 \mu \mathrm{M}$ NEF appeared smaller and denser, typical of apoptotic cells. Labeling with $\mathrm{TMRM}^{+}$suggested a small increase in $\Delta \Psi_{\mathrm{m}}$, and mitochondrial superoxide anion levels appeared to increase. Previous reports have shown that apoptosis may be preceded by mitochondrial hyperpolarization, to which mitochondrial depolarization associated with caspase activation follows (Cao et al., 2007; Giovannini et al., 2002; Iijima et al., 2003; Liu et al., 2005; Sanchez-Alcazar et al., 2000). In this study, hyperpolarization is only visible in some cells while others are clearly depolarized, indicating different stages of apoptotic engagement among the same cell population. These observations reinforce the role of mitochondrial dysfunction in NEF toxicity for lower NEF concentrations, which was also confirmed in glucose-deprived HepG2 cells adapted to rely on oxidative phosphorylation. In these cells, $20 \mu \mathrm{M}$ NEF was already toxic after $24 \mathrm{~h}$ treatment. Treatment with the lower NEF concentration decreased cell mass to 0.41 times compared to DMSO, and this toxicity persisted for the other time points. This was accompanied by a decrease in cell mass to 0.22 times for $48 \mathrm{~h}$, and 0.14 times for $72 \mathrm{~h}$, when compared to DMSO, being always lower when compared to the same conditions in cells cultured in glucose-containing medium. These results are in accordance with previous reports (Dykens et al., 2008; Nadanaciva et al., 2007) and are suggestive of mitochondrial involvement in NEF hepatotoxicity.

These alterations were accompanied by early gene expression changes. At $24 \mathrm{~h}$, a mild increase in the expression of the gene encoding for the transcription factor FOXO3 and small increases in FOS and JUN transcripts. Transcripts for the p53-induced apoptotic genes NOXA and PUMA were also mildly increased. NOXA and PUMA are p53-inducible pro-apoptotic proteins that belong to the BH3-only family of proteins involved in the activation of the intrinsic apoptotic pathway, either by directly binding and inhibiting Bcl-2 anti-apoptotic proteins, or by the direct activation of Bax and Bak pro-apoptotic proteins (Khoo et al., 2014).

However, PCNA transcripts were largely decreased, in accordance with the decrease in proliferation observed with the SRB assay. PCNA plays a main role in DNA replication and it is also involved in other cellular processes including chromatin remodeling, DNA repair, sister-chromatid cohesion and cell cycle control, affecting cell proliferation (Strzalka and Ziemienowicz, 2011).

Mitochondrial DNA-encoded transcript ATP8 was also decreased, although two other mitochondrial transcripts were not affected, indicating that mitochondrial DNA transcription was mildly affected.

The higher NEF concentration $(50 \mu \mathrm{M})$ decreased cell mass to 0.41 times at $48 \mathrm{~h}$, and 0.21 times at $72 \mathrm{~h}$, comparatively to DMSO alone. After $48 \mathrm{~h}$ of exposure, the higher NEF concentration increased the number of permeabilized (apoptotic) cells. At $72 \mathrm{~h}$ of exposure, the number of dead cells was significantly decreased. 
Interestingly, for this concentration NEF did not increase the activity of caspases- 9 or -3 at any of the time points studied. Nonetheless, apoptotic nuclei were also observed for the higher NEF concentration at both treatment times. Cell nuclei appeared smaller and denser, even more than what was observed in cells treated with the lower NEF concentration. The smaller size combined with the denser appearance of nuclei suggests that these cells may have undergone pyknosis, one of the major hallmarks of the apoptotic process, resulting from chromatin condensation (Elmore, 2007; Kerr et al., 1972). These events are suggestive of the occurrence of caspase-independent apoptosis after exposure to the higher NEF concentration.

Both NEF concentrations $(20 \mu \mathrm{M}$ and $50 \mu \mathrm{M})$ and at both treatment times ( $48 \mathrm{~h}$ and $72 \mathrm{~h}$ ) led to alterations on HepG2 cell mass and on nuclear morphology, comparatively to non-treated cells, consistent with the results obtained in the SRB assay for cells growing in glucose medium, and with previous reports (Dykens et al., 2008).

A decrease in $\mathrm{TMRM}^{+}$labeling in cells treated with the higher NEF concentration indicates mitochondrial depolarization. Under these conditions the probability of PTP opening increases and further collapse of $\Delta \psi_{\mathrm{m}}$ can occur. The decrease in $\Delta \psi_{\mathrm{m}}$ observed upon NEF treatment can be related with inhibition of OXPHOS complexes, and may be associated with cell death induction through PTP opening and BAX cascade, leading to cytochrome $c$ release (De Giorgi et al., 2002; Ly et al., 2003). Furthermore, treatment with the higher NEF concentration also increased mitochondrial superoxide levels, in agreement with previous works (Dykens et al., 2008).

In HepG2 cells adapted to rely on oxidative phosphorylation, $50 \mu \mathrm{M}$ NEF was toxic after $24 \mathrm{~h}$ of treatment, decreasing cell mass to 0.18 times compared to DMSO, and this toxicity persisted for the other time points, with cell masses of 0.11 times for $48 \mathrm{~h}$, and 0.07 times for $72 \mathrm{~h}$, which were always lower compared to the same conditions in cells cultured in glucose-containing medium. This is similar to what occurred for the lower NEF concentration tested, indicating that NEF hepatotoxicity also involves mitochondrial dysfunction for higher NEF concentrations (Nadanaciva et al., 2007).

The described alterations were accompanied by several early gene expression changes, more evident, in general, when compared to the lower NEF concentration. After $24 \mathrm{~h}$ treatment there was a drastic increase in the expression of genes encoding for the transcription factors FOS and JUN, which compose the activator protein-1 (AP1), involved in the transcription of several genes associated with apoptosis, including TNF-alpha, FAS-L and BAK (Angel and Karin, 1991; Fan and Chambers, 2001).

Transcripts for the p53-inducible apoptotic genes NOXA and PUMA were also highly increased. PCNA transcripts were significantly decreased, but not as much as observed with the lower NEF concentration. Decrease in PCNA transcripts may enhance the cytotoxic effect of NEF on HepG2 cells compromising normal cell proliferation, Decreased PCNA expression also supports the idea that cell death upon NEF treatment can not only be related with apoptosis induction but also with cell cycle arrest (Maga and Hubscher, 2003).

ATR transcripts were also significantly decreased. The ATR protein is a primary regulator of the replication stress response, with a main role in viability of replicating human and mouse cells and it is activated every S-phase to regulate replication origin firing, repair stalled replication forks, and prevent early entry into mitosis (Cimprich and Cortez, 2008; Cortez et al., 2001; Shechter et al., 2004). Decreased ATR expression can compromise the ability of HepG2 cells to repair DNA and to survive to possible DNA lesions induced by NEF. Thus, the induction of apoptosis upon NEF treatment may be related with ROS generation and compromised of OXPHOS function, but may also be associated with a decrease in cellular ability to respond to DNA damage induced by NEF.

Additionally, all the mitochondrial-encoded transcripts tested were also decreased, indicating an impairment of mitochondrial transcription, and suggesting that NEF treatment may compromise normal mitochondrial function by affecting mitochondrial transcription, impairing the normal assembly of respiratory chain complexes and consequently compromising OXPHOS activity. Therefore, NEF treatment can affect the ability of mitochondria to generate ATP and compromise cell survival.

\section{Conclusions}

NEF compromises normal mitochondrial and cell function, through a mechanism that results in the increased expression of genes associated with DNA-damage response, antioxidant defense and apoptosis and in the decreased expression of genes encoding proteins with a main role in oxidative phosphorylation, DNA repair, cell proliferation, antioxidant defense and cell cycle progression. Thus, HepG2 cell loss upon NEF treatment seems to be a multidimensional process, involving a set of steps and targets that compromise mitochondrial function and cell survival.

\section{Acknowledgments}

This work was funded by the Foundation for Science and Technology, Portugal, grants UID/NEU/04539/2013, PTDC/DTP-FTO/ 2433/2014, PTDC/SAU-TOX/117912/2010, IF/01316/2014, and fellowship SFRH/BPD/101169/2014 to T.C-O, also co-funded by FEDER/Compete and National funds and CENTRO-07-ST24-FEDER002008. We thank the MICC Unit at the Center for Neuroscience and Cell Biology for the help in microscopy imaging. The funding bodies had no role in manuscript content or decision to publish.

\section{Transparency document}

Transparency document related to this article can be found online at http://dx.doi.org/10.1016/j.fct.2016.06.001.

\section{References}

Angel, P., Karin, M., 1991. The role of Jun, Fos and the AP-1 complex in cellproliferation and transformation. Biochim. Biophys. Acta 1072 (2-3), 129-157. Aranda-Michel, J., Koehler, A., Bejarano, P.A., Poulos, J.E., Luxon, B.A., Khan, C.M., Ee, L.C., Balistreri, W.F., Weber Jr., F.L., 1999. Nefazodone-induced liver failure: report of three cases. Ann. Intern Med. 130 (4 Pt 1), 285-288.

Barbhaiya, R.H., Buch, A.B., Greene, D.S., 1996. Single and multiple dose pharmacokinetics of nefazodone in subjects classified as extensive and poor metabolizers of dextromethorphan. Br. J. Clin. Pharmacol. 42 (5), 573-581.

Bradford, M.M., 1976. A rapid and sensitive method for the quantitation of microgram quantities of protein utilizing the principle of protein-dye binding. Anal. Biochem. 72, 248-254.

Cao, J., Liu, Y., Jia, L., Zhou, H.M., Kong, Y., Yang, G., Jiang, L.P., Li, Q.J., Zhong, L.F., 2007. Curcumin induces apoptosis through mitochondrial hyperpolarization and mtDNA damage in human hepatoma G2 cells. Free Radic. Biol. Med. 43 (6), 968-975.

Choi, S., 2003. Nefazodone (Serzone) withdrawn because of hepatotoxicity. CMAJ 169 (11), 1187.

Christmann, M., Kaina, B., 2013. Transcriptional regulation of human DNA repair genes following genotoxic stress: trigger mechanisms, inducible responses and genotoxic adaptation. Nucleic Acids Res. 41 (18), 8403-8420.

Chu, X., Korzekwa, K., Elsby, R., Fenner, K., Galetin, A., Lai, Y., Matsson, P., Moss, A. Nagar, S., Rosania, G.R., Bai, J.P., Polli, J.W., Sugiyama, Y., Brouwer, K.L., International Transporter, C., 2013. Intracellular drug concentrations and transporters: measurement, modeling, and implications for the liver. Clin. Pharmacol. Ther. 94 (1), 126-141.

Cimprich, K.A., Cortez, D., 2008. ATR: an essential regulator of genome integrity. Nat. Rev. Mol. Cell Biol. 9 (8), 616-627.

Cortez, D., Guntuku, S., Qin, J., Elledge, S.J., 2001. ATR and ATRIP: partners in checkpoint signaling. Science 294 (5547), 1713-1716.

De Giorgi, F., Lartigue, L., Bauer, M.K., Schubert, A., Grimm, S., Hanson, G.T., 
Remington, S.J., Youle, R.J., Ichas, F., 2002. The permeability transition pore signals apoptosis by directing Bax translocation and multimerization. FASEB J. 16 (6), 607-609.

Dykens, J.A., Jamieson, J.D., Marroquin, L.D., Nadanaciva, S., Xu, J.J., Dunn, M.C., Smith, A.R., Will, Y., 2008. In vitro assessment of mitochondrial dysfunction and cytotoxicity of nefazodone, trazodone, and buspirone. Toxicol. Sci. 103 (2), 335-345.

Elmore, S., 2007. Apoptosis: a review of programmed cell death. Toxicol. Pathol. 35 (4), 495-516.

Eloubeidi, M.A., Gaede, J.T., Swaim, M.W., 2000. Reversible nefazodone-induced liver failure. Dig. Dis. Sci. 45 (5), 1036-1038.

Fan, M., Chambers, T.C., 2001. Role of mitogen-activated protein kinases in the response of tumor cells to chemotherapy. Drug Resist Updat 4 (4), 253-267.

Gerencser, A.A., Chinopoulos, C., Birket, M.J., Jastroch, M., Vitelli, C., Nicholls, D.G., Brand, M.D., 2012. Quantitative measurement of mitochondrial membrane potential in cultured cells: calcium-induced de- and hyperpolarization of neuronal mitochondria. J. Physiol. 590 (12), 2845-2871.

Giovannini, C., Matarrese, P., Scazzocchio, B., Sanchez, M., Masella, R., Malorni, W., 2002. Mitochondria hyperpolarization is an early event in oxidized low-density lipoprotein-induced apoptosis in Caco-2 intestinal cells. FEBS Lett. 523 (1-3), 200-206.

Horst, W.D., Preskorn, S.H., 1998. Mechanisms of action and clinical characteristics of three atypical antidepressants: venlafaxine, nefazodone, bupropion. J. Affect Disord. 51 (3), 237-254.

Iijima, T., Mishima, T., Akagawa, K., Iwao, Y., 2003. Mitochondrial hyperpolarization after transient oxygen-glucose deprivation and subsequent apoptosis in cultured rat hippocampal neurons. Brain Res. 993 (1-2), 140-145.

Kamalian, L., Chadwick, A.E., Bayliss, M., French, N.S., Monshouwer, M., Snoeys, J., Park, B.K., 2015. The utility of HepG2 cells to identify direct mitochondrial dysfunction in the absence of cell death. Toxicol. In Vitro 29 (4), 732-740.

Kent, J.M., 2000. SNaRIs, NaSSAs, and NaRIs: new agents for the treatment of depression. Lancet 355 (9207), 911-918.

Kerr, J.F., Wyllie, A.H., Currie, A.R., 1972. Apoptosis: a basic biological phenomenon with wide-ranging implications in tissue kinetics. Br. J. Cancer 26 (4), 239-257.

Khoo, K.H., Verma, C.S., Lane, D.P., 2014. Drugging the p53 pathway: understanding the route to clinical efficacy. Nat. Rev. Drug Discov. 13 (3), 217-236.

Kim, J.A., Han, E., Eun, C.J., Tak, Y.K.. Song, J.M., 2012. Real-time concurrent monitoring of apoptosis, cytosolic calcium, and mitochondria permeability transition for hypermulticolor high-content screening of drug-induced mitochondrial dysfunction-mediated hepatotoxicity. Toxicol. Lett. 214 (2), 175-181.

Kostrubsky, S.E., Strom, S.C., Kalgutkar, A.S., Kulkarni, S., Atherton, J., Mireles, R. Feng, B., Kubik, R., Hanson, J., Urda, E., Mutlib, A.E., 2006. Inhibition of hepatobiliary transport as a predictive method for clinical hepatotoxicity of nefazodone. Toxicol. Sci. 90 (2), 451-459.
Liu, M.J., Yue, P.Y., Wang, Z., Wong, R.N., 2005. Methyl protodioscin induces G2/M arrest and apoptosis in K562 cells with the hyperpolarization of mitochondria. Cancer Lett. 224 (2), 229-241.

Lucena, M.I., Andrade, R.J., Gomez-Outes, A., Rubio, M., Cabello, M.R., 1999. Acute liver failure after treatment with nefazodone. Dig. Dis. Sci. 44 (12), 2577-2579.

Ly, J.D., Grubb, D.R., Lawen, A., 2003. The mitochondrial membrane potential (deltapsi(m)) in apoptosis; an update. Apoptosis 8 (2), 115-128.

Maga, G., Hubscher, U., 2003. Proliferating cell nuclear antigen (PCNA): a dancer with many partners. J. Cell Sci. 116 (Pt 15), 3051-3060.

Marroquin, L.D., Hynes, J., Dykens, J.A., Jamieson, J.D., Will, Y., 2007. Circumventing the Crabtree effect: replacing media glucose with galactose increases susceptibility of HepG2 cells to mitochondrial toxicants. Toxicol. Sci. 97 (2), 539-547.

Nadanaciva, S., Bernal, A., Aggeler, R., Capaldi, R., Will, Y, 2007. Target identification of drug induced mitochondrial toxicity using immunocapture based OXPHOS activity assays. Toxicol. In Vitro 21 (5), 902-911.

Sanchez-Alcazar, J.A. Ault, J.G., Khodjakov, A., Schneider, E., 2000. Increased mitochondrial cytochrome c levels and mitochondrial hyperpolarization precede camptothecin-induced apoptosis in Jurkat cells. Cell Death Differ. 7 (11), 1090-1100.

Shechter, D., Costanzo, V., Gautier, J., 2004. Regulation of DNA replication by ATR: signaling in response to DNA intermediates. DNA Repair (Amst) 3 (8-9) 901-908.

Strzalka, W., Ziemienowicz, A., 2011. Proliferating cell nuclear antigen (PCNA): a key factor in DNA replication and cell cycle regulation. Ann. Bot. 107 (7), 1127-1140.

Swiss, R., Niles, A., Cali, J.J., Nadanaciva, S., Will, Y., 2013. Validation of a HTSamenable assay to detect drug-induced mitochondrial toxicity in the absence and presence of cell death. Toxicol. In Vitro 27 (6), 1789-1797.

Swiss, R., Will, Y., 2011. Assessment of mitochondrial toxicity in HepG2 cells cultured in high-glucose- or galactose-containing media. Curr. Protoc. Toxicol. Chapter 2 (Unit2), 20.

Vega-Naredo, I., Cunha-Oliveira, T., Serafim, T.L., Sardao, V.A., Oliveira, P.J., 2015. Analysis of pro-apoptotic protein trafficking to and from mitochondria. Methods Mol. Biol. 1241, 163-180.

Vichai, V., Kirtikara, K., 2006. Sulforhodamine B colorimetric assay for cytotoxicity screening. Nat. Protoc. 1 (3), 1112-1116.

von Moltke, L.L., Greenblatt, D.J., Granda, B.W., Grassi, J.M., Schmider, J, Harmatz, J.S., Shader, R.I., 1999. Nefazodone, meta-chlorophenylpiperazine, and their metabolites in vitro: cytochromes mediating transformation, and P4503A4 inhibitory actions. Psychopharmacol. Berl. 145 (1), 113-122.

Wang, Y., Zhou, Y., Graves, D.T., 2014. FOXO transcription factors: their clinical significance and regulation. Biomed. Res. Int. 2014, 925350.

Xu, J.J., Henstock, P.V., Dunn, M.C., Smith, A.R., Chabot, J.R., de Graaf, D., 2008 Cellular imaging predictions of clinical drug-induced liver injury. Toxicol. Sci. 105 (1), 97-105. 